\title{
STUDENT'S EXPERIENCE OF E-LEARNING, LEARNING PROCESS AND PERCEIVED LEARNING OUTCOMES IN ECONOMIC MATH COURSE
}

\author{
Yunia Mulyani Azis ${ }^{a *)}$, Henny Suharyati ${ }^{b)}$, Sussy Susanti ${ }^{a)}$ \\ ${ }^{a)}$ STIE Ekuitas, Bandung, Indonesia \\ ${ }^{b)}$ Pakuan University, Bogor, Indonesia \\ ${ }^{*}$ Corresponding Author: yuniams@yahoo.com
}

Article history: received 25 June 2019; revised 15 July 2019; accepted 26 August 2019

\begin{abstract}
This paper reveals research findings about the effect of E-learning experiences on student learning outcomes felt for Mathematics Economics courses. This study examines perceived learning outcomes in terms of effectiveness, number and productivity of learning in the context of E-learning. The participants were undergraduate students at the School of Economis EKUITAS. The results are interpreted using quantitative and verification research approaches. The results show that the E-learning experience of students is significantly correlated with learning process, and have indirect effect on perceived learning outcomes. This study uses a learning model developed by Biggs and Moore. Specific recommendations for practitioners are also given, and their implications for educators are discussed. Finally, suggestions for further research on E-learning are provided.
\end{abstract}

Keywords: E-learning experience; learning model; learning outcomes

\section{INTRODUCTION}

In the last decade, information technology and the internet have experienced very rapid developments that have enabled learning methods to experience innovation such as e-learning. This makes colleges and universities are required to use e learning widely. The lecturers are also required to have teaching skills in e-learning so that this learning method can improve student learning outcomes.

This research about E-learning is intended to be able to provide a better understanding of the benefits of the Elearning method. Ultimately it aims to uncover the link between their perceptions about E-learning experiences and, their relationship with perceived learning outcomes as presented in the learning model developed by Biggs and Moore [1].

This research is a continuation of extraordinary work done by researchers (Haverila, [2]), which shows that student readiness in e-learning is positively correlated with student learning outcomes felt. In the results of the study it was shown that "e-learning learning readiness" as a factor consisted of the following variables: perceptions of the speed of learning, increased learning, easier learning, suitability of E-learning with individual needs, suitability of learning styles for E-learning, and attitude. while the "ability and interest" factor consists of the following variables: active learners, motivation levels, and time management. However, the ability and interest factors are not positively correlated with the perception of student learning outcomes in the study.

Today, online learning is part of the student experience for most students in various countries (eg, Ituma, [3]; Otter et al., [4]; Tucker et al., [5]) and much research has focused on efficiency, content and methods deliveries have been developed by teaching staff (for example, Rossman [6]; Twigg [7]; O'Neill et al.[8]), while students' own perceptions and experiences have not been much investigated (Alexander [9]; Holley and Oliver [10]; Ituma [3]). This research tries to fill this gap. This course is the first experience of E-learning students. The inclusion of previous E-learning experiences will complement the Biggs and Moore [1] learning models used in previous research projectse.

\section{Biggs and Moore's Learning Model}

The research question in this study is the extent to which students' E-learning experiences influence the perception of student learning outcomes in the Mathematics Economics course. Based on previous research, Biggs and Moore [1] made the 3P learning model a theoretical framework. The 3Ps referred to are Presage, Process and Product. The "Presage" section contains pre-existing student experience variables. In the "Process" section, students' perceptions of their learning environment are evaluated. This perception influences students' choices about learning strategies and how these strategies are applied. The Product Component contains the student's perceived performance results (effectiveness, number, and productivity). A similar multivariable approach, different from using only one variable (eg satisfaction only), was also adopted by Wang [11] in assessing learning effectiveness. Other research in this area is consistent with Biggs and Moore's model, which shows that prior learning experiences, learning concepts, and student learning approaches support the quality of student learning outcomes (Gravoso et al.[12]). Table 1 includes 
examples of representative variables that can be used in the learning model in each section (Cybinski \& Selvanathan [13]).

Table 1. The 3P model of student learning

\begin{tabular}{|l|l|l|}
\hline Presage & Process & Product \\
\hline Student variables, intellectual capability.(IC) & Student motivation and & Exam results, self- \\
\hline and abilities, prior knowledge, subject area, & behavior, Student & concept, grade point \\
teaching methods, personality, culture, home & learning strategies. & average, satisfaction. \\
\hline background, time constraints, course structure. & & \\
\hline
\end{tabular}

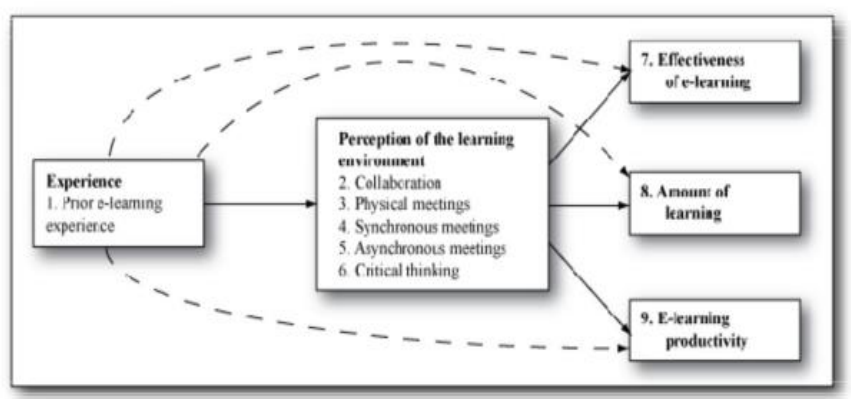

Figure 1. The modified 3P model of student perceptions (dotted lines indicate the potential direct effects)

Experience in E-learning is examined as an independent variable (Liaw [14]). Both direct and indirect effects through process variables are measured. In the Cybinski and Selvanathan studies [13]), traditional exams at the end of the semester are used to measure the effectiveness of overall learning. In this study, evaluation of performance tests is not used as a criterion of effectiveness, but rather on student learning outcomes. This method complements Cybinski and Selvanathan's [13] approach by using the joy of enjoyment and judgment as a process variable.

On the basis of the previous statement, the first research hypothesis in this study is:

H1: E-learning experiences of students have a significant effect on the learning process.

Furthermore, this study also seeks to verify whether the student experience variable impacts the learning outcome variable through the learning process.

$\mathrm{H} 2$ : The learning process has a significant effect on the learning outcome variable

\section{RESEARCH METHODS}

The research method that will be used in this study is a survey method with a quantitative approach. The object in this study is STIE Equity students who take economics mathematics courses where the variable measured 3P includes Presage, the process of contributing to learning outcomes. In accordance with the proposed proposition, a statistical study that is suitable for a causal model (cause and effect) will be used, namely Partial Least Square (PLS-SEM) analysis with consideration to overcome deviations from the normality assumption and adequacy of the sample.

\section{Population and Research Samples}

In this study the population was all STIE Equity students. Based on respondents who returned the questionnaire only 57 respondents from the questionnaire distributed so that the study sample consisted of only 57 students.

\section{Method of collecting data}

Data collection method used to obtain information and data is filling out a questionnaire / questionnaire which is a method for collecting primary data using a set of questionnaires about variables measured through careful planning, arranged and packaged in such a way that the answers to all questions can really describe the state of the actual variable.

\section{Data analysis method}

This research uses Partial Least Square (PLS) as an analysis tool. In this case, students' e-learning experiences, learning processes, and learning outcomes are treated as latent variables with each indicator. PLS is one method to carry out modeling using SmartPLS software. This PLS model is used when the basic theory of designing a weak model and measurement indicators do not meet the ideal measurement model. PLS can be used with a number of samples that are not large and can be applied at all data scales.

\section{Model Analysis \\ Learning Outcome $=\gamma_{31}$ Learning Process $+\zeta_{2}$ Learning Process $=\beta_{32}$ Student's experience $+\zeta_{1}$}

\section{RESULTS AND DISCUSSION}

Evaluation of measurement models (outer models)

Test Validity

An indicator is declared valid if it has a loading factor above 0.5 for the intended latent variable. Validity testing for reflective indicators uses the correlation between item scores and the latent variable scores. Measurement with reflective indicators shows a change in an indicator in a latent variable if other indicators in the same latent variable change (or are excluded from the model). Reflective indicators are suitable for measuring perceptions so this study uses reflective indicators. Reflective indicators also need to be tested for discriminant validity by cross loading as follows: 
Tabel 2. Result For Cross Loading

\begin{tabular}{|l|c|c|c|}
\hline & $\begin{array}{c}\text { Product } \\
\text { (Learning Outcome) }\end{array}$ & Experience & Process \\
\hline P11 & 0.048465 & $\mathbf{0 . 8 0 1 5 6 0}$ & 0.556853 \\
\hline P21 & 0.225705 & 0.436747 & $\mathbf{0 . 8 3 4 9 6 1}$ \\
\hline P22 & 0.183772 & 0.614723 & $\mathbf{0 . 9 5 5 3 6 7}$ \\
\hline P23 & 0.343574 & 0.607251 & $\mathbf{0 . 8 7 7 3 1 1}$ \\
\hline P24 & 0.262605 & 0.501214 & $\mathbf{0 . 7 5 0 7 8 7}$ \\
\hline P25 & 0.301759 & 0.116852 & $\mathbf{0 . 6 3 1 7 0 2}$ \\
\hline P26 & 0.449887 & 0.556921 & $\mathbf{0 . 8 4 2 1 1 1}$ \\
\hline P31 & $\mathbf{0 . 7 4 0 8 5 3}$ & 0.172565 & 0.383402 \\
\hline P32 & $\mathbf{0 . 8 2 3 4 5 1}$ & 0.068363 & 0.390223 \\
\hline P33 & $\mathbf{0 . 8 1 4 8 2 4}$ & 0.230312 & 0.297788 \\
\hline
\end{tabular}

An indicator is declared valid if it has the highest loading factor to the intended latent variable compared to the loading factor to other latent variables. The table above shows that the loading factor for indicators P21 through P25 has a higher loading factor for the latent process variable than the other latent variables. The same thing also appears in other indicators. Thus the indicator is declared valid in measuring latent variables

\section{Reliability Test}

Reliability test is done by looking at the composite reliability value of the indicator block that measures latent variables. The reliability composite results will show a satisfactory value if above 0.7 . Here are the composite reliability values in the output:

Table 3. Composite Reliability

\begin{tabular}{|c|c|}
\hline & Composite Reliability \\
\hline Experience & 0.835274 \\
\hline Process & 0.899857 \\
\hline Learning Outcome & 0.860608 \\
\hline
\end{tabular}

The above table shows that the value of composite reliability for all latent variables are above 0.7 indicating that all the latent variables in the model were estimated to meet the criteria of discriminant validity. Reliability of the lowest composite value is equal to 0.835274 on e-learning experience latent variables. Reliability test can also be strengthened by Cronbach's Alpha where output SmartPLS Version 2 gives the following results:

Table 4. Cronbach's Alpha

\begin{tabular}{|c|c|}
\hline Experience & $\begin{array}{c}\text { Cronbachs } \\
\text { Alpha }\end{array}$ \\
\hline Process & 0.755577 \\
\hline Learning Outcome & 0.831475 \\
\hline
\end{tabular}

The recommended value is above 0.6 and the table above shows that the Cronbach's Alpha value for all constructs is above 0.6. The lowest value is 0.755577 (Student's experience).

\section{Inner Model Test}

Once the model is estimated meets the criteria Outer Model,subsequent testing of structural models (Inner model). Following are the R-Square values on latent variables:

Table 7. R-Square

\begin{tabular}{|c|c|}
\hline & R Square \\
\hline Students experience & \\
\hline Learning Oute & 0.394908 \\
\hline Process & 0.191431 \\
\hline
\end{tabular}

The table above gives the value of 0.394908 for latent variables, which means that the Learning outcomes capable of explaining the variance process of $39.4908 \%$. R-square value is also present in the process is influenced by students' e learning experience that is 0.191431 , which means The process is influenced by the experience of $19.143 \%$. Hypothesis testing is as follows:

Tabel 8. Inner Model Test

\begin{tabular}{|c|c|c|c|}
\hline & $\begin{array}{c}\text { coefficient } \\
\text { model }\end{array}$ & standard error & t statistics \\
\hline $\begin{array}{c}\text { E-learning } \\
\text { experience -> } \\
\text { Process }\end{array}$ & 0,4375 & 0,072 & 6,0787 \\
\hline $\begin{array}{c}\text { Process -> } \\
\text { Learning outcome }\end{array}$ & 0,6284 & 0,0642 & 9,7825 \\
\hline
\end{tabular}

The table above shows that the relationship between e-learning experiences and processes is significant with a $\mathrm{T}$ statistic of 6.079 (> 1.96). The coefficient value is positive that is equal to 0.4375 which indicates that the direction of the relationship between the e-learning experience with the process is positive. Thus the hypothesis in this study which states that 'e-learning experiences affect the process' is accepted

The table above shows that the relationship between Process and Learning Outcomes is significant with a $\mathrm{T}$ statistic of 9.7825 (> 1.96). The coefficient value is positive that is equal to 0.6284 which indicates that the direction of the relationship between the Process and Learning Outcomes is positive. Thus the hypothesis in this study which states that 'Process influences Learning Outcomes' is accepted.

\section{CONCLUSION}

Based on the results and discussion, this research can be concluded that 
1. There is a significant influence between e-learning experiences on the Learning Process. The importance of the E-learning process variable will increase when students become more familiar with E-learning

2. There is a significant influence of e-learning experience on indirect learning outcomes through the process as an intervening variable, meaning that to improve the learning outcomes of STIE Equity students can be done by improving the learning process first because the elearning experience has no direct effect.

\section{Recommendation}

Based on the conclusions presented above, recommendations can be made from the findings of this study, namely:

1. In improving student learning outcomes, students should pay attention to the learning process as an intervening variable, because previous students' e-learning experiences alone do not directly affect learning outcomes. The practical step to improve this learning process is to pay attention to collaboration between lecturers and students, physical meetings, synchronized and non-synchronized meetings and critical thinking (Entwhistle, McCune and Walker [15])

2. In addition, educational institutions that provide elearning must accommodate students with previous elearning experiences such as e-learning socialization by gathering all STIE Equity students before the e-learning lecture begins.

3. The principle underlying constructivism is that true knowledge is built from positive experiences (Applefield, Huber, \& Moallem, [16]) and this also applies to E-learning. Finally, because E-learning can be very complex, it is recommended that additional features be combined. As part of the learning process, the right virtual learning environment is important to use, appropriate resources are used, students' technical skills are improved to match the requirements required in E-learning, and the time allocated for learning is properly assessed (Pirani, [17]) .

\section{REFERENCES}

[1] Biggs, J., \& Moore, P. 1993. The process of learning 3rd. ed. Australia: Prentice Hall.

[2] Haverila, M. 2009. Factors Related to Perceived Learning Outcomes in an Undergraduate E-learning Course. Accepted for publication in International Journal of Knowledge and Learning, forthcoming.

[3] Ituma, A. 2011. An evaluation of students' perceptions and engagement with e-learning components in a campus based university. Active Learn. High. Educ. 12, 57-68. 2011. doi: 10.1177/1469787410387722.
[4] Otter, R. R., Seipel, S., Graeff, T., Alexander, B., Boraiko, C., Gray, J., et al. 2013. Comparing student and faculty perceptions of online and traditional courses. Internet High. Educ. 19, 27-35. doi: 10.1016/j.iheduc.2013.08.001

[5] Tucker, B., Halloran, P., and Price, C. 2013. "Student perceptions of the teaching in online learning: an Australian university case study," in Research and Development in Higher Education: The Place of Learning and Teaching, Vol. 36, eds S. Frielick, N. Buissink-Smith, P. Wyse, J. Billot, J. Hallas, and E. Whitehead (Auckland: Higher Education Research and Development Society of Australasia), 470-484.

[6] Rossman, M. H. 1999. "Successful online teaching using an asynchronous learner discussion forum". J. Asynchronous Learn. Netw. 3, 1-8.

[7] Twigg, C. 2002. Improving learning and reducing costs: new models for online learning. Educause Review, Sept/Oct, 28-38.

[8] O’Neill, K., Singh, G., and O’Donoghue, J. 2004. Implementing elearning programmes for higher education: a review of the literature. J. Inf. Technol. Educ. 3, 313-323.

[9] Alexander, S. 2001 E-learning developments and experiences. Educ. Train. 43, 240-248.

[10] Holley, D., and Oliver, M. 2010. Student engagement and blended learning: portraits of risk. Comput. Educ. 54, 693-700. 2010.

[11] Wang, Y. 2003. Assessment of learner satisfaction with asynchronous electronic learning systems.

[12] Gravoso, R.S., Pasa, A.E., \& Mori, T. 2002. Influence of students' prior learning experiences, learning conceptions and approaches on their learning outcomes. Retrieved from: www.ecu.edu.au/ conferences/herdsa/main/papers/ref/pdf/Gravoso.pdf

[13] Cybinski, P., \& Selvanathan, S. 2005. Learning experience and learning effectiveness in undergraduate statistics modeling performance in traditional and flexible learning environments. Decision Sciences The Journal of Innovative Education, 3, 251-271,

[14] Liaw, S. 2008. Investigating students' perceived satisfaction, behavioral intention, and effectiveness of E-learning: A case study of the Blackboard System. Computers \& Education, 51, 864-873,

[15] Entwhistle, N., McCune, V., \& Walker, P. 2002. Conceptions, styles and approaches within higher education: analytic abstractions and everyday life. In R.J. Sternberg \& L. Zhang (Eds.), Perspectives on Thinking, Learning, and Cognitive Styles.

[16] Applefield, J.M., Huber, R. \& Moallem, M. 2001. Constructivism in theory and practice: Toward a better understanding. The High School Journal, 84, 35-53,

[17] Pirani, J.A. 2004. Supporting E-learning in higher education. 2004. 